\title{
The Bangladesh Competition Law - Improving the Efficiency of the Market
}

\author{
A.K. Enamul Haque \\ Professor, Department of Economics, East West University, Bangladesh
}

\section{INTRODUCTION}

The economy of Bangladesh is the $41^{\text {st }}$ largest economy in the world. This means only 40 countries in the world are bigger than Bangladesh. To put things into perspective, the Malaysian economy is only 18\% bigger than Bangladesh's and if the current growth rates persist, the Bangladeshi economy overtake the Malaysian economy by 2025 . However, pursuing economic growth requires careful planning. There is a need to ensure continuous economic growth and promotion of justice and equity in the society. In this aspect, a market, which is a source of economic growth, needs to be fair. If it is controlled by a few, it may lead to both inequality and exploitation in society. In this situation, consumers pay a higher price and new and small producers cannot enter the market. As such, there is a need to ensure that the markets remain competitive.

In this context, the competition laws are used by governments to ensure that the markets remain fair and so it continues to extract investments, protects young investors and brings prosperity in the society. This article analyzes the Competition Act of Bangladesh with a view to understand its implications for the economy of Bangladesh. Since the law is yet to be fully implemented so this article provides a comparative legal analysis in order to see how it might be implemented through regulations in order to achieve the objectives of the law as stipulated in its preamble.

\section{HISTORY OF THE BANGLADESH COMPETITION ACT}

The Government of Bangladesh enacted the Competition Act in 2012. In the Preamble, the Act stated that,

"WHEREAS in the context of gradual economic development of the country, it is expedient and necessary to make provisions to promote, ensure and sustain congenial atmosphere for the competition in trade, and to prevent, control and eradicate collusion, monopoly and oligopoly, combination or abuse of dominant position or activities adverse to the competition". ${ }^{1}$

Passing of the law, however, is only the first step towards fulfilling its goal. In fact, it took two years for the Government of Bangladesh to establish the Bangladesh Competition Commission in 2014. This, however, was not enough because there was a need to approve a regulation to begin proper functioning of the Commission. A most vital component of the law is also to develop appropriate awareness on the rules and

1 The Competition Act 2012. 
procedures on the competition law so that it can be applied and also used by the victims to protect them against unfair market behaviors. The most difficult part of implementing such law is that the terms and the concepts used to charge a business with anti-competitive behavior are alien to common legal practitioners.

As it has been mentioned earlier, the primary goal of the law is to promote consumer's welfare through elimination of anti-competitive practices in the market. However, economic literature does not clearly stand for or against any practice and label them as 'anti-competitive'. It is the intent and the consequences of the practice that define a behavior as anti-competitive rather than the behavior itself. This makes it difficult to label a market behavior as bad or good. As such it is important to analyze how, other countries or regions used this law to promote market competition.

\section{EU AND US LAWS AND THEIR IMPACTS}

The EU competition law has three major objectives (among others) and they are: a) consumer protection, b) redistribution, and c) protection of competitors. ${ }^{2}$ The first competition law in the world was, however, the Sherman Antitrust Act of 1890 in the US and was the first formal law to prohibit formation of a monopoly or similar behavior in a market for any product or service.

"The Sherman Antitrust Act-proposed in 1890 by Senator John Sherman from Ohio-was the first measure passed by the U.S. Congress to prohibit trusts, monopolies, and cartels. The Sherman Act also outlawed contracts, conspiracies, and other business practices that restrained trade and created monopolies within industries". ${ }^{3}$

Although the US law and the EU law had different objectives in mind, they have many common tools to detect anti-competitive practices. However, the differences between them are still visible in their practices as these economies began to take actions against any anti-competitive practices in a market. One of the hidden objectives of the law in both EU and US was to prohibit the creation of monopoly behavior in the market. Monopoly or a cartel behavior in a market often allows one or few producers to accumulate wealth. The competition laws, on the other hand, had an underlying intention of ensuring economic equity rather than economic efficiency alone. The impact of the actions taken by the Commission on companies to ensure equity, however, did not always guarantee the intended results. For example, the decision by the US Competition Commission to split the Standard Oil in 1911 eventually created bigger wealth. According to the Economist:

AMERICAN courts do not much like breaking up successful companies. But when they do, the results are not always dire. Think of Exxon, Mobil, Amoco, Chevron: those companies, with a long and valuable history, are among the fragments of Standard Oil, broken up in 1911. In the subsequent decade, the

\footnotetext{
2 Richard Whish and David Bailey, Competition Law (9 $9^{\text {th }}$ Edition, Oxford University Press 2018).

Will Kenton, 'Sherman Antitrust Act Definition' (Investopedia) <https://www.investopedia.com/ terms/s/sherman-antiturst-act.asp> accessed 30 January 2021.
}

Page $\mid 232$ 
value of Standard Oil's divided assets rose fivefold. John D. Rockefeller, lucky man, thus made more money in retirement than during his working life. ${ }^{4}$

It is, therefore, important to carefully interpret the economic consequences of an anticompetitive behavior rather than defining them as 'anti-competitive' per se. The Bangladesh Competition Act, 2012 provided several definitions on anti-competitive practices and in the following sections, a few of the sections of the Act is analyzed in terms of their impact on market competition.

\section{ANTI-COMPETITIVE AGREEMENTS}

\section{A. Collusive agreements}

The Bangladesh Competition Act, 2012 defined an anti-competitive agreement in Section 15(1) as:

"any agreement or collusion, in respect of production, supply, distribution, storage or acquisition of any goods or services which causes or is likely to cause an adverse effect on competition or creates monopoly or oligopoly in the market".

This shows that anti-competitive agreements are expected to be between producers or suppliers with an objective to cause an adverse effect - implying increase in price - by creating monopoly or oligopoly in the market. The implication of such a broad definition is rather scary because, by definition, any oligopoly market (and of course a monopoly market) will result in increase in price. Thereby, the most important aspect is to examine the word 'adverse effect' and provide reliable evidence towards it. This means, does it mean to say that any agreement of cooperation is necessarily anticompetitive?

It is difficult to interpret this as there are evidence to show that cooperation may also reduce inefficiency. For example, when multiple cable operators compete for subscribers in one single area, it may lead to increased subscription prices because of high initial investment costs. On the contrary, it they cooperate and divide their service areas through a mutual agreement, it will reduce the service charges for subscribers and bring efficiency in the market. Cable TV operators in Dhaka, have formed a cartel as only one cable TV operator operates in any area of Dhaka.

Accordingly, it can be concluded that the cartel of Cable TV operators did neither lead to inefficiency nor did it result in accumulation of wealth and hence, a sweeping conclusion to define any agreement for formation of a cartel in an oligopoly market as an anti-competitive practice might work against the ultimate objective of the law.

\section{B. Abnormal Purchases or Bid Rigging}

\footnotetext{
4 'Bill Rockefeller?' (The Economist, 29 April 2000) <https://www.economist.com/leaders/ 2000/04/27/bill-rockefeller> accessed 30 January 2021.

5 The Competition Act 2012.
} 
Section 15(2) (a) of the Competition Act, 2012 states that:

The practice or decision of any person or association of persons engaged in any agreement, any trade of identical or similar goods or in any provision of services shall be deemed to have adverse effect on competition in the market of goods or services if it:

(a) directly or indirectly

(i) determines abnormal purchase or sale prices; or

(ii) determines the deceptive price in all process including bid rigging; ${ }^{6}$

This section stipulates that firms or individuals engaged in agreements that have both direct or indirect impact in the market in terms of 'abnormal purchase or sale prices' or 'deceptive prices in all process' are deemed anti-competitive.

From a pure economic theory point of view, such a definition is dangerous unless there is a clear definition of 'abnormal' price behavior. For example, the Ministry of Commerce in 2007 imposed a draconian rule under which a price difference between wholesale and retail prices beyond $10 \%$ is called 'abnormal' and hence required actions to be taken against the businesses. Such an interpretation of 'abnormal' behavior is simply frightening. To explain this, let me use the following simple case:

'A' - a retailor purchased a produce from 'B' - the wholesaler, at a price of Taka 100. Imagine that A sells the same product in the same market on the same day at a price of Taka 105 which is below the $10 \%$ limit set by the government. This means by investing 100 Taka A has earned 5 Taka in one day. Now, let us assume that ' $A$ ' reinvest his 100 Taka in the same way on the following day and so on. Therefore, in one year, 'A' makes 5 x $365=1825$ Taka from his capital of 100 Taka, an equivalent of $1825 \%$. The question is whether this is a 'normal' or 'abnormal' rate of profit?

On the other hand, economic theory suggests that rate of profit depends for factors; a) efficiency in management, b) innovation; c) risk in doing business and d) frictional behaviors. Hence, there is a need to define the term 'abnormal' based on factors that influences profit. For example, a 10\% may seem to be a 'normal' profit rate in a retail vegetable market but it may not be so in product like medicine which requires years of research to invent a medicine and yet it is also susceptible to high rate of piracy by potential competitors. Forcing a low rate of profit on them, may lead to complete collapse of the market.

\section{Tie-in Agreements}

Section 15(3) of the Competition Act, 2012 defines several anti-competitive practices in a market. Section (15)(3)(a) states that

“'tie-in arrangement', that is to say, an agreement or understanding requiring

6 ibid.

Page | 234 
a purchaser of goods, as a condition of such purchase, to purchase some other goods or to receive any benefit from the seller or any other person or enterprise engaged by him;" 7

There are cases when it can be awfully hard to define such tie-in arrangements as anticompetitive. For example, android operating system requires people to use 'android' compatible apps. Google does not allow non-android apps to be used in its android devices. A software developer needs to enroll them into the Google Ad services to receive and share income with Google. Clearly, Google has created a tie-in arrangement and it does benefit from it. Is this an anti-competitive behavior?

\section{Exclusive Supply Agreements}

Section 15(3) (b) defined 'exclusive supply agreement' and it states:

"'exclusive supply agreement', that is to say, an agreement restricting in any manner the purchaser in the course of his trade from acquiring or otherwise dealing in any goods other than those of the seller" 8

There are many supply agreements that restricts buyers from acquiring other goods from another seller. Such agreements could be horizontal as well as vertical implying that a producer may restrict its buyer from purchasing products of other suppliers. A good example of this is like an agreement for price fixing by different suppliers of one product. Agreement on airfare between competing airlines or on bus fares between competing bus companies are not uncommon and yet not all of them are necessarily price distorting. One should be careful in distinguishing these agreements (overt or covert) with that of restricting supplies to increase prices. It is the latter type of horizontal agreements often accused of distorting the market.

\section{E. Exclusive Distribution Agreements}

Section 15(3)(c) defines 'exclusive distribution agreement' as:

“' exclusive distribution agreement', that is to say, an agreement which limits, restricts or withholds the output or supply of any goods or allocates any area or market for the disposal or sale of the goods",

This is the most common practice among suppliers in the market and are also labelled as 'vertical agreements' and are often practiced by a producer in the market chain. A car manufacturer appointing a company as exclusive distributor for its cars, or a retailer entering into an agreement to ensure that its supplier do not share the same product to other retailers are very common and may not always cause significant harm. In fact, competition pundits often regard vertical agreements as less distorting than that of horizontal agreements. ${ }^{10}$ However, a vertical agreement designed to prevent others to

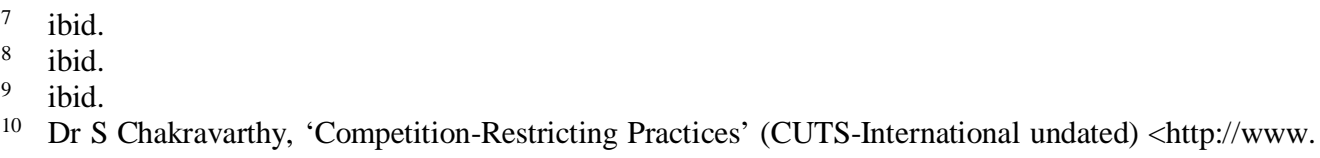

10 Dr S Chakravarthy, 'Competition-Restricting Practices' (CUTS-International undated) <http://www. 
enter the market is an anti-competitive practice and hence shall be punished.

\section{F. Refusal to Deal}

Section 15(3)(d) explains 'refusal to deal' issues of anti-competitive behavior:

"refusal to deal", that is to say, an agreement which restricts, by any manner the persons or classes of persons to whom goods are sold or from whom goods are bought; ${ }^{.1}$

This behavior is difficult to trace but often exists in a market. For example, a credit card company forcing retailers to only respect its credit card and refuse other cards to clear payments or an insurance company entering into a contract with a hospital to only treat patients using the health insurance card of the company are not difficult to find in the market. It possible that such arrangement might restrict other competitors to survive in the market. Similarly, if a retail chain-shop refuses to sell products of a producer it might also restrict competition in the market or it might lead to elimination of a potential competitor. For instance, in the Sherman Act, 1890 group boycott is classified as illegal per se. ${ }^{12}$

\section{G. Resale Price Maintenance}

Section 15(3)(e) of the Competition Act 2012 defines the 'resale price' policy related anti-competitive behavior. It states:

"resale price maintenance", that is to say, an agreement to sell goods on condition that the prices to be charged on the resale by the purchaser shall be the prices stipulated by the seller unless it is clearly stated that prices lower than those prices may be charged.

Manufacturer of a product often control the retail price of their products. It can be used to restrict competition in the market. In a market, retailers often compete to maximize their revenue. For example, a retailor might sell a product free or at a low price to attract customers. Many grocery shops sell milk or egg at a low price to attract customers visit the shop and purchase other products. Such cross-subsidization may be part of their business policy. An agreement to prohibit such practice has been defined as anti-competitive by law. It is particularly for this reason; we often see the label 'maximum retail price' instead of 'retail price' set by the manufacturer on many products.

\section{H. Abuse of dominance}

Abuse of dominance is another aspect of anti-competitive practices in many markets.

\footnotetext{
cuts-international.org /NTW/pdf/Paper-2-Namibia.pdf> accessed 03 May 2021.

11 The Competition Act 2012.

12 Will Kenton (n 3).

Page $\mid 236$
} 
Buyers or sellers may use their market power (either as a buyer or as seller) to restrict competition in the market. In US, for example, blue-cross health insurance was accused of such practice when it initiated an informal contract with hospitals to exclusively provide services to their insurance card holders. In EU, Google was accused of similar practices as it distributed the internet explorer - an internet browser, at free of charge and so it was effectively hatching a plan to kill Mozilla. In the Competition Act 2012, Section 16 defines this as:

if an enterprise -

(a) imposes directly or indirectly unfair or discriminatory condition in purchase or sale of goods or services or discriminatory price or predatory price in purchase or sale of goods or services;

(b) limits or restricts production of goods or provision of services or market thereof or technical or scientific development relating to goods or services to the prejudice of consumers;

(c) indulges in practice or continue to do practices which prevents others to access in the market;

(d) makes conclusion of contracts subject to acceptance by other parties of supplementary obligations which, by their nature or according to commercial usage, have no connection with the subject of such contracts; or

(e) uses its dominant position in one relevant market to enter into, or protect, other relevant market. ${ }^{13}$

In this definition, the legal text has used certain terms that require some explanations. These are predatory pricing and unfair or discriminatory pricing.

In addition to these, it is possible that producers might also abuse their market power through creating deliberate 'misinformation' through its advertisements. The Canadian Competition Act explicitly stated that misleading or deceptive advertisements is also an anti-competitive behavior. It states that:

"These include sections relating to bait-and-switch advertising, promotional contests, deceptive prize notices, double ticketing, testimonials, electronic advertising, "ordinary selling price" claims and sales, performance claims, multi-level marketing and pyramid selling schemes, sales above advertised prices and telemarketing." 14

Manufacturers using 'false' testimonials to mislead customers is an age-old practice in Bangladesh. It allows large producers to target young producers and dominate the

13 The Competition Act 2012.

14 Steve Szentesi Law Professional Corporation, 'Competition Law | Toronto Lawyer Offering Canadian Competition, Advertising and Regulatory Law Services' <http://www.ipvancouverblog.com/> accessed 31 January 2021. 
market.

\section{Other Relevant Aspects}

Besides the above-mentioned aspects as described in the Bangladesh Competition Act, 2012 , there are other practices and issues which should also be brought under the scanner of the Competition Authority in order to implement the Competition Act, 2012 effectively. In this section, we summarize a few of them based on the practices similar laws in other countries.

\section{Spams}

In modern marketing, electronic and telemarketing strategies are gaining strength. During the COVID-19, many producers have moved into the e-commerce platform to sell their products and services. Using hidden tools to influence customers through misleading or disseminating 'selected' information might also be a tool to abuse dominance by large producers. In the Bangladesh Competition Law, these were not stipulated and hence are not included in the explanation on abuse of dominance.

\section{Leniency}

Crimes under 'anti-competitive' behavior are hard to trace because their effects are not easy to trace. In particular, it is often difficult to trace 'cartel' which is a collusive behavior among a 'closely held group of producers'. Cracking cartels is often difficult. Understanding this, many of the competition laws across the world, Pakistan ${ }^{15}$, and India ${ }^{16}$ for example, included a provision for leniency under which lesser punishment may be awarded to a producer for providing information that leads to punishment of the members of the cartel. Such a provision is important because it will allow the Competition Commission to crack cartels in any market. Unfortunately, such a provision does not exist in the Competition Act of Bangladesh.

\section{CONCEPTS AND TOOLS FOR ASSESSING ANTI-COMPETITIVE BEHAVIOUR}

The Competition Commissions across the world vehemently prosecute businesses which are engaged in anti-competitive activities and distort the market. However, the primary focus of the Commissions is 'about the way in which business should be conducted $^{17}$ and so it may not always be about ensuring consumer's welfare. For example, reducing price may always benefit consumers but in the long run it may lead to reduction in the number of competitors in the market and so in some cases commissions around the world intervened and forced the market players to change their behavior. It is more about creating conditions for fair trading or ensuring fair price of

15 Competition Commission of Pakistan, 'Competition Commission Of Pakistan - Competition Act' $<$ https://www.cc.gov.pk/index.php?option=com_content\&view=article\&id=60\&Itemid=110\&lang=e $\mathrm{n}>$ accessed 2 February 2021.

16 The Competition Act 2002 (India).

17 Richard Whish and David Bailey (n 2).

Page $\mid 238$ 
a product or a service in the market.

In this connection there are economic concepts that shall be defined and tested during the legal process. Some of these concepts are discussed below.

\section{A. Market Definition}

Defining the market may be quite tricky in terms of understanding the behavior. Take the example of Microsoft. It has been providing the operating system for personal computers. In order to give better services, it included an application called 'Windows Media' free. The question is, is the application a part of the operating system or a part of application to listen to music? The competitions in each of the market are different. In the music player market, it competes with 'Real Player', VLC, and many others. Whereas in the operating system is competes with Linux. The EU Competition Commission defined these two markets separately and so penalised Microsoft for supplying the Windows Media free while selling the operating system. In this case, the definition of the market is important and the EU imposed penalty on Microsoft and forced them to stop supplying it free. "What is the 'relevant market'?", remains an important consideration for the Commissions. For the purpose of defining the 'relevant market', EU, UK and also US competition commissions use an SSNIP (small but significant and non-transitory increase in price) test also known as 'hypothetical monopolist' test. It provides a specific and objective assessment for the prosecutor to define the 'relevant market'. To put simply, the hypothetical monopoly test assesses the impact of changes in behavior of producers in one market on another market. This test is particularly relevant in case analysis of merger cases or in case of agreements leading to non-competitive markets.

\section{B. Relevant product}

In the market there are many similar products and it becomes difficult for a commission to determine the 'relevant products' for a product in question. The concept relies on the measurement of interchangeability. There are several tests used by the European Commissions and that of US to define relevant products. In the case of Europemballage Corpn and Continental Can Col Inc. $v$ Commission, ${ }^{18}$ the European Court of Justice quashed the decision of the Competition Commission for its failure to define the 'relevant market'. One way to define interchangeability is to use the legal test meaning that when the goods and services are interchangeable it is within the same product market. In case of the United Brands $v$ Commission $^{19}$, the plaintiff argued that 'bananas are in the same market as other fruits' and the European Court of Justice held that whether bananas could be

"singled out by such special features distinguishing it from other fruits that it is only to a limited extent interchangeable with them and is only exposed to their competition in a way that is hardly perceptible”. ${ }^{20}$

A second strategy is to measure interchangeability between products. In many cases,

18 ibid.

19 ibid.

20 United Brands v Commission (1978) Case No. 27/1976, 1 CMLR 129, para 22 (ECJ). 
however, it may be difficult to observe in practice due to lack of reliable data. There are also issues of demand-side substitutability where changes in specification in one product may lead to creating monopoly in another product. In case of horizontal mergers, it may be important to use demand side substitutability to determine the relevant products. The European Commission defined 'relevant products' in terms of product characteristics, prices and intended use by consumers. ${ }^{21}$ Competition Commissions across the world use several techniques including econometric analysis including estimation of cross-price elasticities as an evidence of substitutability.

\section{Relevant Geographic markets}

It is often argued that two products may be substitutable in one market and not in the other. For example, while in a community pork meat is a substitute product of other meats, it may not be same in another community. Similarly, merger of two companies in one market may reduce competition but it may not be so in another market because there are other substitutes. Competition Commissions, while defining 'relevant market' also consider such cases implying that there could be both demand-side and also supply-side substitutability between markets in two locations.

\section{Temporal Market}

Competition conditions may vary across seasons and consequently it is possible that the firm faces a fierce competition in one season while it may be a dominant firm in another season.

\section{E. Consumers' Survey}

Consumer's survey is also a tool used by Competition Commissions across the world to define substitutability or interchangeability of products. However, it is important to note that such survey does not use any ad hoc method to elicit consumer's mind or ask questions in such a way to achieve favourable outcome.

\section{F. Market Power}

Market power is a measurement of competitive behavior in a market. It can be measured using index of market share or market concentration. The HerfindahlHirchman Index (HHI) is often used as a tool to measure the market power. The HHI is measured in a market using square of market shares of all competitors in a market.

$$
=\sum 2
$$

Where $\mathrm{s}$ is the market share of the competitor and $\mathrm{s}$ is measured a value of the market share. For example $\mathrm{s}=10$ if the share is $10 \%$,

21 'Relevant Market', (Wikipedia, 2020)

$<$ https://en.wikipedia.org/w/index.php?title=Relevant_market\& oldid=940239033> accessed 3

February 2021.

Page $\mid 240$ 
The market concentration is low if $\mathrm{HHI}$ is below 1000, moderate if it is between 1000 and 1800 and high it is above 1800 .

\section{G. Barriers to Expansion and Entry}

Barriers to expansion and entry is also assessed to understand the nature of competition in a market. The Director General of Competition of the European Commission in their discussion paper exclusionary abuses defined several factors that may be considered giving rise to barriers. ${ }^{22}$ These are: a) legal barriers - such as limiting number of firms to acquire licenses or conferring intellectual rights to one that may prevent others to enter the market; b) capacity constraints - like huge sunk costs to enter the market; c) economies of scale - meaning expansion may lead to continuous fall in the average cost; d) privileged access to supply - a firm having an advantage because of its ownership of a component of production; e) highly developed distribution and sales network - which may bar others to enter the market with a substitution product and so on.

\section{CONCLUSION}

The Bangladesh economy is growing. Unlike many other growing economies, its economic activities are run by the private sector. As the Bangladesh economy expands with a growth rate of more than 7 or 8 percent, it is generating significant opportunity to earn profit for the private sector. A simple calculation would reveal that if, for example, a 320-billion-dollar economy grows at the rate of 7\%, it means we expect at least 38 billion dollars ${ }^{23}$ worth additional value or economic activity added to our economy in the following year. This is an opportunity to earn more profit and an economy without competition will increase inequality and hence will lead to concentration of wealth in the hands of a small group of entrepreneurs. It is in this context that the implication of the competition law should be understood. The competition law, if implemented well, ensures equal opportunities for all entrepreneurs, reduces inequality and helps create a just society.

22 DG Competition Commission, EU, 'Discussion Paper on the Application of Article 82' (European Commission 2005).

$237 \%$ real economic growth plus 5\% inflation $=12 \%$ nominal growth of GDP 
Dhaka University Law Journal, Centennial Special Issue, Vol. 32(1)

Page | 242 